\title{
CHANGE IN AIR QUALITY DURING COVID-19 LOCKDOWN OVER SMALL INDUSTRIAL CITY: CHANDRAPUR
}

\author{
Pankaj Chimurkar \\ Mechanical Department, \\ Rajiv Gandhi College of \\ Engineering Research and \\ Technology, Chandrapur, \\ India.
}

\author{
Shailendra R Zaveri \\ Mechanical Department, \\ Rajiv Gandhi College of \\ Engineering Research and \\ Technology, Chandrapur, \\ India.
}

\author{
Pranay Sathe \\ Mechanical Department, \\ Rajiv Gandhi College of \\ Engineering Research and \\ Technology, Chandrapur, \\ India.
}

\begin{abstract}
In the light of COVID-19 pandemic with many negative consequences, the environment is facing some positive changes due to lesser human activity as many nations have declared complete lockdown. India enforced complete lockdown between 24 Mar 2020 and 31 May 2020 which heavily limits vehicles from unnecessary movements. Thus emissions due to vehicles might have reduced. We investigate the impact of lockdown on small industrial city Chandrapur, India. The results show PM2.5 and $\mathrm{PM}_{10}$ have decreased over Chandrapur, relatively more in the City Centre than the Industrial area Khutala. The pollutants like $\mathrm{NO}_{2}, \mathrm{SO}_{2}$, and $\mathrm{CO}$ are not showing many changes that may be due to uninterrupted industrial activities. The decline is very less compared to metro cities.
\end{abstract}

Keywords - Chandrapur, COVID-19, PM2.5, Air Quality, India

\section{INTRODUCTION}

The COVID-19 has claimed a million lives worldwide and India stands among the top five worst-affected nations [1]. The pandemic has questioned many aspects of human life and with no cure so far, all nations have decided to limit their unnecessary things so that spread of this virus can be controlled. The lesser human activities like transport due to lockdown can reduce air pollution. Some studies have conducted over India show that the pandemic has reduced pollution levels more than $50 \%$ over big cities like Delhi and pollutants like $\mathrm{NO}_{2}$ and $\mathrm{CO}$ has reduced 52 and $30 \%$ respectively $[2,3]$. Such a large reduction could be good news for human beings as more than 4 million people die each year due to higher pollution level [4]. Similar reduction in the air quality is also reported in the China, Tehran, Malaysia, Brazil, Italy and Iran [5-10].
The studies have only conducted on bigger cities of India but an investigation of air quality over smaller cities is missing. This study investigates air pollution levels during lockdown over Chandrapur, India, a city which is located in central India, lies between 18.4 to 20.5 degrees North Latitude and 78.5 to 80.6 East longitudes. It is famous for higher pollution due to more number of Industries in the surrounding, Including Chandrapur Super Thermal Power Plant. Many media houses have reported Chandrapur as the most polluted city in India $[11,12]$. However, the recent study shows that Chandrapur has much lesser pollution levels than other metro cities [13]. This study aims to distinguish the difference in the impact of national lockdown over Chandrapur and other cities especially Delhi.

\section{DATA AND METHOD}

India announced a complete lockdown from 24 March 2020 to 31 May 2020 with partial movement permitted to important things (Hospitals, Groceries, and Police force). This lockdown is also strictly followed by Chandrapur city, which has impacted traffic patterns of the city. Chandrapur city has two pollution monitoring stations by state pollution control board jointly working with the central pollution control board (CPCB). The data for $\mathrm{PM}_{2.5}, \mathrm{PM}_{10}, \mathrm{NO}_{2}, \mathrm{SO}_{2}$, and $\mathrm{CO}$ between 1 January 2020 and 25 June 2020 are downloaded using the CPCB portal (https://app.cpcbccr.com/ccr/\#/caaqmdashboard-all/caaqm-landing/data) for both the stations. The location of two stations, the city centre and Khutala are shown in figure 1 , both the stations are $7 \mathrm{~km}(15 \mathrm{~min}$ driving distance) apart from each other. The city centre is the station located in the centre of Chandrapur city, and Khutala is the station located in the industrial area of the city.

The study investigates three periods, 1 Jan 2020 to 23 Mar 2020 (Pre-Lockdown), 24 Mar 2020 to 31 May 2020 (Lockdown), and 1 Jun 2020 to 25 Jun 2020 (Post). The percentage change has calculated with respect to the Pre- 


\section{International Journal of Engineering Applied Sciences and Technology, 2020}

Vol. 5, Issue 2, ISSN No. 2455-2143, Pages 419-422

Published Online June 2020 in IJEAST (http://www.ijeast.com)

Lockdown period for all five pollutants. The analysis is performed using Google Sheets an online platform. is $0.32,0.40$, and $0.45 \mathrm{mg} / \mathrm{m}^{3}$ during Pre-Lockdown, Lockdown and Post-Lockdown respectively.

The opposite of $\mathrm{CO}, \mathrm{SO}_{2}$ in the city centre seems very

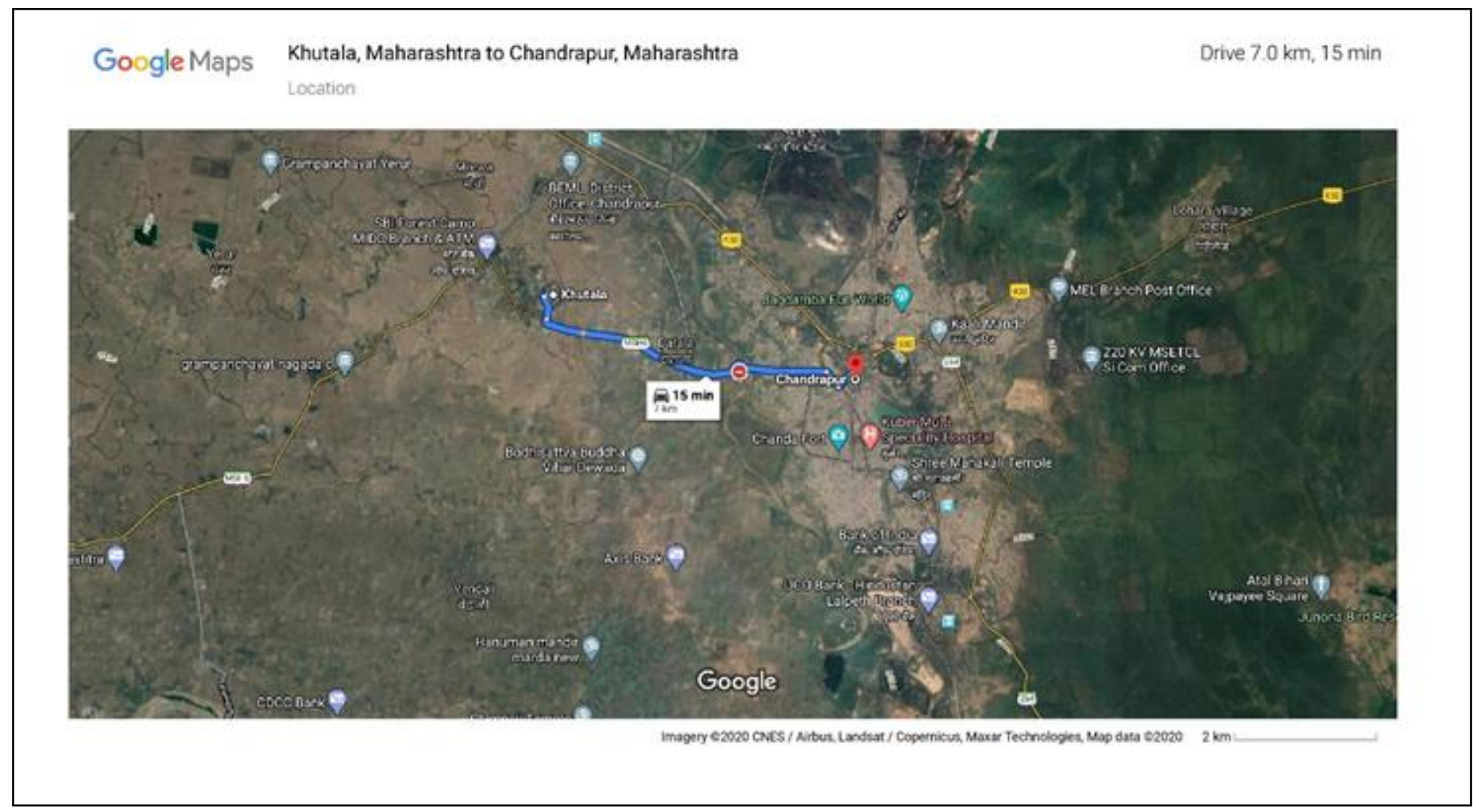

Fig. 1. Location and distance between two stations. (Source: Google Maps)

\section{RESULTS}

$\mathrm{PM}_{10}$ over the city centre is higher than the Khutala region and more decrease of the concentration can be seen in the PostLockdown period as shown in figure 2 may be due to frequent monsoon rain. The $\mathrm{PM}_{10}$ in the city centre is 78.95, 75.00, and $47.68 \mu \mathrm{g} / \mathrm{m}^{3}$, while, $\mathrm{PM}_{10}$ in the Khutala is 42.92, 30.30, and $13.14 \mu \mathrm{g} / \mathrm{m}^{3}$ during Pre-Lockdown, Lockdown and PostLockdown respectively.

$\mathrm{PM}_{2.5}$ also shows a similar nature as a concentration in the city centre is $42.92,30.30$, and $13.14 \mu \mathrm{g} / \mathrm{m}^{3}$, while, $\mathrm{PM}_{2.5}$ in the Khutala is $34.75,33.87$ and $16.31 \mu \mathrm{g} / \mathrm{m}^{3}$ during PreLockdown, Lockdown and Post-Lockdown respectively. Some of the data during Pre-Lockdown were missing.

The CO shows a very strange pattern, the Khutala region shows very fewer fluctuations than the city centre which may because of constant industrial activities, while, concentration in the city centre depends on the human activities near the station which varies with the day. The $\mathrm{CO}$ concentration near the city centre is $0.35,0.30$, and $0.25 \mathrm{mg} / \mathrm{m}^{3}$, while, $\mathrm{CO}$ in the Khutala stable and Khutala shows dynamic nature in the daily $\mathrm{SO} 2$ concentrations. $\mathrm{SO}_{2}$ shows $8.49,24.41$, and $23.84 \mu \mathrm{g} / \mathrm{m}^{3}$ concentration in the city centre, while, $\mathrm{SO}_{2}$ in the Khutala is 12.85, 17.78, and $10.18 \mu \mathrm{g} / \mathrm{m}^{3}$ during Pre-Lockdown, Lockdown and Post-Lockdown respectively.

The $\mathrm{NO}_{2}$ concentrations in the city centre are $10.26,12.82$, and $12.08 \mu \mathrm{g} / \mathrm{m}^{3}$, while, $\mathrm{NO}_{2}$ in the Khutala is 7.30, 20.46, and $11.00 \mu \mathrm{g} / \mathrm{m}^{3}$ during Pre-Lockdown, Lockdown and PostLockdown respectively.

The recent study over Chandrapur showing annual concentration of 42.08 , and $10.92 \mu \mathrm{g} / \mathrm{m}^{3}$ for $\mathrm{PM}_{2.5}$, and $\mathrm{SO}_{2}$, while, $0.48 \mathrm{mg} / \mathrm{m}^{3}$ for $\mathrm{CO}$ respectively [13]. These concentrations are much more similar to what have been found in present study.

Table -1 The average concentration of pollutants. All units are in $\mu \mathrm{g} / \mathrm{m} 3$ except $\mathrm{CO}\left(\mathrm{mg} / \mathrm{m}^{3}\right)$.

\begin{tabular}{llrrrrr} 
& & \multicolumn{1}{c}{$\mathrm{PM}_{2.5}$} & \multicolumn{1}{c}{$\mathrm{PM}_{10}$} & \multicolumn{1}{c}{$\mathrm{NO}_{2}$} & \multicolumn{1}{c}{$\mathrm{SO}_{2}$} & \multicolumn{1}{c}{$\mathrm{CO}$} \\
\hline \multirow{3}{*}{ City Centre } & Pre-lockdown & 42.92 & 78.95 & 10.26 & 8.49 & 0.35 \\
& Lockdown & 30.30 & 75.00 & 12.82 & 24.41 & 0.30 \\
& Post-Lockdown & 13.14 & 47.68 & 12.08 & 23.84 & 0.25 \\
\hline \multirow{3}{*}{ Khutala } & Pre-lockdown & 34.75 & 64.35 & 7.30 & 12.85 & 0.32 \\
& Lockdown & 33.87 & 58.94 & 20.46 & 17.78 & 0.40 \\
& Post-Lockdown & 16.31 & 30.59 & 11.00 & 10.18 & 0.45 \\
\hline
\end{tabular}


Table -2 The percentage change in pollutants with respect to PreLockdown.

\begin{tabular}{|c|c|c|c|c|c|c|}
\hline & & $\mathrm{PM}_{2.5}$ & $\mathrm{PM}_{10}$ & $\mathrm{NO}_{2}$ & $\mathrm{SO}_{2}$ & $\mathrm{CO}$ \\
\hline \multirow{2}{*}{ City Centre } & \% Lockdown & -29.40 & -5.01 & 24.96 & 187.40 & -14.25 \\
\hline & $\%$ Post-Lockdown & -69.39 & -39.61 & 17.74 & 180.74 & -27.82 \\
\hline \multirow{2}{*}{ Khutala } & \% Lockdown & -2.53 & -8.41 & 180.28 & 38.31 & 23.43 \\
\hline & $\%$ Post-Lockdown & -53.06 & -52.47 & 50.74 & -20.79 & 39.25 \\
\hline
\end{tabular}

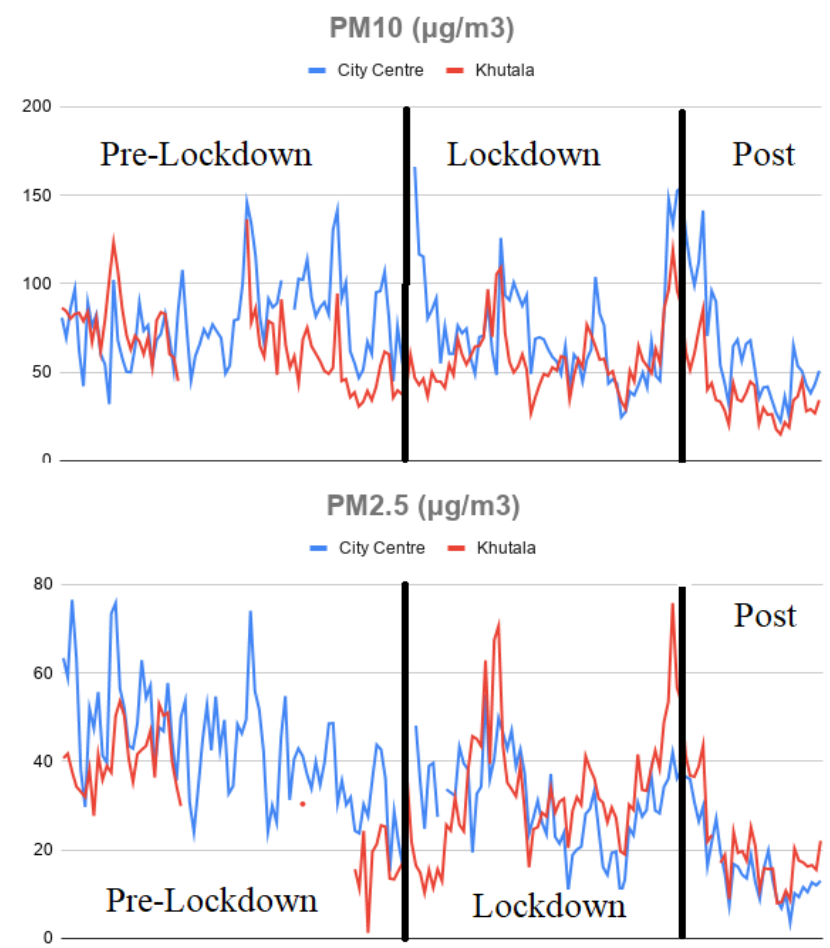

Fig. 2. Time series of $\mathrm{PM}_{2.5}$ and $\mathrm{PM}_{10}$ for the city centre and Khutala

Fig. 2. The percentage change shown in table 2 suggests that the concentrations during lockdown have not changed much. $\mathrm{PM}_{2.5}, \mathrm{PM}_{10}, \mathrm{NO}_{2}, \mathrm{SO}_{2}$ and $\mathrm{CO}$ shows -29.4, -5.0, 24.96, 187.4 and $-14.25 \%$ change in city centre, however, Khutala shows $-2.5,-.8 .4,180.2,38.3$ and $23.4 \%$ changes during Lockdown respectively. Whereas, the change for $\mathrm{PM}_{2.5}, \mathrm{PM}_{10}$, $\mathrm{NO}_{2}, \mathrm{SO}_{2}$, and $\mathrm{CO}$ reported $-69.39,-39.6,17.7,180.74$, and $27.82 \%$ in the city centre, however, Khutala shows -53.06 , 52.47, 50.74, -20.79 and $39.25 \%$ changes during-Post Lockdown respectively.

Compared to the reported decline in previous studies, these changes are very uncertain and less. This may imply that the lockdown may not have affected Chandrapur city much due to the presence of industries nearby. While the higher decline in the Post-Lockdown period may be due to the frequent rain showers over the city than can wash out the pollutants from the air.

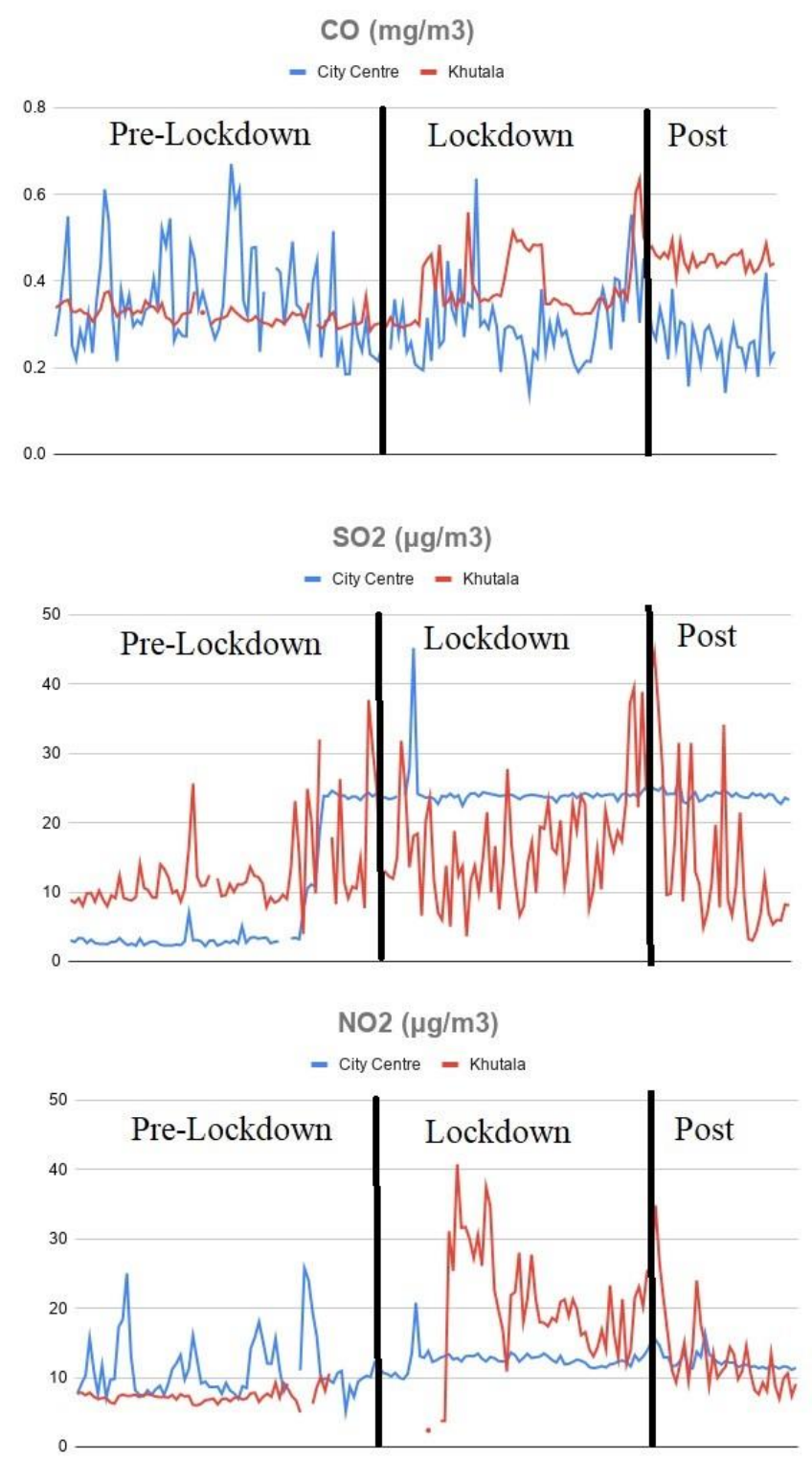

Fig. 3. Time series for $\mathrm{CO}, \mathrm{SO}_{2}$, and $\mathrm{NO}_{2}$ for the city centre and Khutala

\section{CONCLUSION}

The study shows that the decline in pollution levels is not as high as over Delhi, with a very lesser decline in the Lockdown period. $\mathrm{PM}_{2.5}$ and $\mathrm{PM}_{10}$ show -29.4 and $-5.0 \%$ decline over City Centre, while, Khutala reported -2.5 and $-8.4 \%$ decline respectively. The decline for the Post-Lockdown period is very high compare to the Lockdown period with respect to the Pre-Lockdown period which may be due to rain. $\mathrm{NO}_{2}$ and $\mathrm{SO}_{2}$ show an increase in the concentration during lockdown that can be the cause of Industrial activities that remain functioning 


\section{International Journal of Engineering Applied Sciences and Technology, 2020 \\ Vol. 5, Issue 2, ISSN No. 2455-2143, Pages 419-422 \\ Published Online June 2020 in IJEAST (http://www.ijeast.com)}

during the lockdown, especially Chandrapur Super Thermal Power Plant which has more than $4000 \mathrm{MW}$ capacity. CO shows a decline over City Centre but Khutala reported an increase during and after Lockdown. Hence we can say that these changes are very less compared to other cities like Delhi reported by recent study. It is very essential to also focus on such small industrial cities which show different behaviour than metro cities.

\section{Acknowledgment}

The authors would like to thanks the Central Pollution Control Board (CPCB) for providing free data. We also thanks to our Institute for providing resources and motivating expertise.

\section{Conflict of Interest}

The authors declared no conflict of interest.

\section{REFERENCE}

[1] WHO. (2020). Coronavirus disease (COVID-19), Situation Report - 109.

[2] Mahato, S., Pal, S. \& Ghosh, K. G. (2020). Effect of lockdown amid COVID-19 pandemic on air quality of the megacity Delhi, India. Sci. Total Environ. 730, 139086.

[3] Sharma, S. et al. (2020). Effect of restricted emissions during COVID-19 on air quality in India. Sci. Total Environ. $728,138878$.

[4] WHO. Air pollution. (2020). Available at: https://www.who.int/health-topics/air-pollution\#tab=tab_1.

[5] Broomandi, P. et al. (2020). Impact of COVID-19 Event on the Air Quality in Iran. Aerosol Air Qual. Res. 20.

[6] Faridi, S. et al. (2020). Impact of SARS-CoV-2 on Ambient Air Particulate Matter in Tehran. Aerosol Air Qual. Res. 20.

[7] Chen, Q.-X., Huang, C.-L., Yuan, Y. \& Tan, H.-P. (2020). Influence of COVID-19 Event on Air Quality and their Association in Mainland China. Aerosol Air Qual. Res. 20.

[8] Dantas, G., Siciliano, B., França, B. B., da Silva, C. M. \& Arbilla, G. (2020). The impact of COVID-19 partial lockdown on the air quality of the city of Rio de Janeiro, Brazil. Sci. Total Environ. 729.

[9] Muhammad, S., Long, X. \& Salman, M. (2020). COVID19 pandemic and environmental pollution: A blessing in disguise? Sci. Total Environ. 728. 138820.

[10] Mohd Nadzir, M. S. et al. (2020). The Impact of Movement Control Order (MCO) during Pandemic COVID19 on Local Air Quality in an Urban Area of Klang Valley, Malaysia. Aerosol Air Qual. Res. 20, 1237-1248.

[11] News: Delhi not the most polluted city, Chandrapur in Maharashtra has the worst air quality. Available at: https://indianexpress.com/article/india/india-news-india/delhiair-pollution-most-polluted-city-air-quality-index-aqi-

3830971/.

[12] News: Chandrapur region most polluted in Maharashtra: Report | Nagpur News - Times of India. Available at: https://timesofindia.indiatimes.com/city/nagpur/chandrapurregion-most-polluted-in-statereport/articleshow/72100205.cms.

[13] Chimurkar, P. \& Zaveri, S. R. (2020). Current Pollution Level and Emissions from Vehicular sector in Chandrapur District. Int. J. Mod. Sci. Technol. 5, 137-141. 